\title{
Far i mors sted - fædre på orlov
}

\section{Af Bente Marianne Olsen}

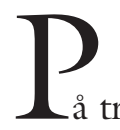

å trods af udbredt ligestilling mellem kønnene er det fortsat usædvanligt, at fædre har eneansvaret for omsorgen af helt små børn, mens mor er på arbejde. I artiklen sandsynliggør jeg ud fra den franske sociolog Pierre Bourdieus begreber om naturalisering, kønnet habitus og androcentrisk orden, at både fædre og mødre forbinder orlov i denne korte periode af barnets liv med noget, der er forbeholdt mødre. Det er med andre ord kulturelt utænkeligt for de fleste forældre og deres omgivelser, at faren skal holde orlov til det spæde barn i stedet for mor. Selv hos fredre, som aktuelt har valgt orlov og påtaget sig hovedansvaret for et lille barns omsorg i en længere periode, forbindes hjemmet og spædbarnet med moderskabet. Jeg viser gennem interview med frdre på orlov, hvordan fæedrene fremstiller deres faderskab i traditionelle maskuline termer. For eksempel beskrives faderskabet ud fra et ideal om udeliv og vild leg med barnet, og barnets udvikling til en selvstændig person tilskrives faderens tilstedeværelse. Med ud- 
gangspunkt i de fă fredre, som faktisk tager orlov, diskuterer og sandsynliggør jeg afslutningsvis, hvorfor de fleste fædre, på trods af at de har rettigheder til orlov, ikke bruger orlovsordningerne i særlig vid udstrækning.

\section{FAR I MORS STED}

De fædre, som jeg har interviewet, kan siges at være på orlov "i mors sted", fordi fædrene tilhører en uhyre lille gruppe fædre, som tager orlov til børnepasning af et spæd- eller meget lille barn, uden at moren samtidig er hjemme (Olsen 2000). Formålet med interviewundersøgelsen var at fă en forståelse af hverdagslivet hos fæedre på orlov til helt små børn. Jeg var interesseret i, hvordan fæedre havde det på et felt, som traditionelt har været domineret af kvinder i det moderne samfund. Jeg havde en række udvælgelseskriterier. De vigtigste var:

1. Fædrene skulle have taget orlov fra et $1 \varnothing$ narbejde, for at jeg kunne belyse fædres opfattelse af forskellen mellem at være på arbejde og være hjemmegående.

2. Fædrene skulle have orlov til et barn under to år, således at fædrene trådte ind i et felt, der normalt er et kvindeligt domæne, når vi taler om spæd- og småbørn i modsætning til at holde orlov til et større barn.

3. Fædrenes partnere måtte ikke være hjemme i dagtimerne under orloven, fordi fædrene skulle have erfaringer med at være eneansvarlige for omsorgsarbejdet.

Jeg regnede i begyndelsen af projektet med, at der var en del fredre på orlov til børnepasning, der passede til disse kriterier, men det var ikke tilfældet. Der findes ingen statistik, der på forhånd kunne have vist det, fordi statistikken kun giver oplysninger om enkeltpersonernes orlovsbenyttelse. Det vil sige, man kan ikke ud af statistikken læse, hvordan et forældrepar tilsammen fordeler deres orlovsperioder til et eller flere fælles børn, fordi de individuelle oplysninger på forældrene ikke sammenkøres med familien som enhed ${ }^{1}$. Det blev først tydeligt gennem et omfattende opsøgende arbejde på at skaffe interviewpersoner, at stort set ingen frdre holder orlov alene til et mindre barn, uden barnets mor samtidig er i hjemmet. Jeg henvendte mig til et par arbejdsformidlinger, som bevilger alle orlovsperioder, til ledende sundhedsplejersker, til lokale fagforeninger og til nogle større virksomheder og hospitaler. Jeg var på denne måde i berøring med over hundrede beskæftigede fædre på orlov, men af dem var der kun 13 fædre, som ikke havde orlov samtidig med deres partner. 13 fædre var således under deres orlov eneansvarlige for pasningen af deres lille barn i dagtimerne og de blev alle interviewet. I alt var der efter mit bedste skøn på det tidspunkt ca. 1000 beskæftigede fædre på landsplan på orlov til et lille barn, hvor moren ikke også var hjemme (Olsen 2000 p. 9). I dag er der endnu færre, da antallet af både fædre og mødre på orlov til børnepasning er faldet kraftigt ${ }^{2}$.

\section{TO KøN, TO ORLOVSMØNSTRE}

Fædre på orlov til børn under to år er således et sjældent fænomen, også sjældnere end først antaget ved undersøgelsens begyndelse. Jeg fandt ud af, at fredre og mødre har meget forskellige orlovsmønstre (Olsen 2000). Op mod $100 \%$ af alle mødre tager barsels- og forældreorlov i de mulige 24 uger, og en tredjedel af alle kvinder med et barn under 6 år har haft orlov til børnepasning til barnet. Oftest tager mødrene orloven i forlængelse af barselsorloven. Stort set alle mødre tager orlov for at være ene ansvarlig for barnet $i$ et længere tidsrum og dermed holde det uden for offentlig dagpasning. Mens fædre, udover at de sjældnere end mødre holder orlov, vælger de typer orlov, hvor de kan være hjemme samtidig med moren. Desuden er de mest populære orlovsordninger blandt mænd dem, der ikke skal forhandles om. Det er de ordninger, der er øremærket til mænd, som de 14 dage, som fæedre har henholdsvis i 
forbindelse med fødslen og i barnets 24 . 26. leveuge (Olsen 2000).

\section{DE FÅ FÆDRES MOTIV TIL ORLOV}

Det er således atypisk for fædre at vælge at være eneansvarlige for et spæd- eller småbarn i en orlovsperiode. Spørgsmålet er, hvad motivet er hos de få fædre, som går mod strømmen og vælger orlov. Man kunne måske forvente, at fædre, der tager et så atypisk valg set $\mathrm{i}$ forhold til de fleste andre fædres fravalg af orlov, har en ide om, at fædre og mødre skal ligestilles, når det gælder omsorgen for spæd- og småbørn. Men det er ikke det, der er på spil for den snævre kreds af fædre, jeg har interviewet.

I analysen af de 13 fæedres beretninger om livet på orlov har jeg analyseret fæedrenes prioritering af lønarbejde og familieliv. Det er klart, at fæedre, der tager orlov, i udgangspunktet må betragtes som meget orienteret mod deres familie i deres prioriteringer, da de jo vælger lønarbejdet fra i orlovsperioden. På trods af at alle fædrene således er familieorienteret i udgangspunktet, er der en klar tendens til, at nogle af fædrene er langt mere familieorienteret $\mathrm{i}$ deres prioriteringer af lønarbejde og familieliv end andre. I det følgende vil jeg derfor henvise til to grupper af fædre på orlov: De familieorienterede og de arbejdsorienterede (Olsen 2000, 169). De familieorienterede er kendetegnet ved, at de holdt lange orlovsperioder, der tillige ofte var længere end deres partneres. Det skyldtes, at de oftest forud for orlov til børnepasning havde haft en del af de 10 ugers forældreorlov, som ligger i barnets 14.-24. uge, og som kan deles mellem forældrene. Generelt underordnede de familieorienterede fædre deres lønarbejde i forhold til deres familieforpligtigelser både før og efter orloven. De arbejdsorienterede fædre holdt den på det tidspunkt mindst mulige orlovsperiode på 13 uger. De udviste stor ansvarlighed for deres job forud for orloven ved blandt andet at arbejde ekstra meget og nogle få ar- bejdede også under orloven. Desuden gav de alle udtryk for, at de savnede deres $1 \varnothing$ narbejde under orloven, hvilket de familieorienterede fædre ikke gjorde.

De familieorienterede og de arbejdsorienterede fædre havde forskellige motiver til at vælge orlov. Man kan spørge sig selv, hvorfor arbejdsorienterede fædre overhovedet vælger at holde orlov og ikke overlader det til deres partnere, som det sker hos langt de fleste andre forældrepar. En mulig forklaring er, at de alle havde det til fælles, at det at blive far havde været vanskeligt og derfor ville de være sammen med barnet, når nu det lykkedes på trods af alle ods. Således havde en far nær mistet sit barn og sin kone ved fødslen, en anden havde et langt forløb bag sig, hvor parret havde forsøgt at få barn, en tredje var blevet så gammel, at han næsten havde opgivet at finde en kæreste og få barn. De familieorienterede frdres motiver til orlov var et stærkt ønske om at være tæt på deres børn, som de allerede realiserede fra barnets fødsel. Fædrene var således aktive i pasningen af det nyfødte barn, både når de havde fri fra arbejde og ved at sørge for at være meget hjemme ved at afspadsere, holde ferie og tage al den orlov, som de havde ret til forud for orlov til børnepasning (dvs. fædreorlov og forældreorlov). Nogle af fædrene var gift med kvinder, der gjorde karriere, og da faren var den mest familieorienterede, var det også ham, der kalkulerede med orlov, indtil barnet kunne komme i offentlig pasning. De øvrige havde partnere, der, som dem selv, var stærkt familieorienterede og parrets fælles mål var at holde barnet ude af pasning længst mulig tid.

\section{TO KøN, TO DISPOSITIONER FOR FORÆLDRESKAB}

Fædre på orlov til et lille barn befinder sig i et rum eller en social situation, som er forbundet med moderskabet. Selv om faren og moren ikke længere opfattes som havende en klar rollefordeling, hvor faren er den 
økonomiske forsørger og moren omsorgsforsørgeren, tyder meget på, at småbørnsforældre fortsat disponerer efter det traditionelle mønster, selv om samfundet levner dem andre muligheder (Olsen 1997). De komplementære roller afløses af en opfattelse hos forældrene om, at de deles om den økonomiske og omsorgsmæssige forsørgelse af barnet (Bäck-Wiklund og Bergsten 1997). Det betyder imidlertid ikke, at der ikke fortsat findes et kønssystem, hvor fædre har en rolle og mødre en anden rolle, men rollerne fremstår mere utydeligt end tidligere, og de er til forhandling i rgteskabet (Haavind 1995).

Den norske socialpsykolog Hanne Haavind skriver, at faderskabet og moderskabet forstås ud fra to forskellige fortolkningsrammer, som gensidigt udelukker hinanden. Hun eksemplificerer det med, at når små-børnsmødre reflekterer over forskelle $\mathrm{i}$ deres og partnerens hverdagsliv, sammenligner de ikke sig selv med deres partnere. De sammenligner sig med deres mødre og de ser friheden i deres eget liv i relation til deres mødres liv med små børn (Haavind 1987).

Samme pointe findes hos den franske sociolog Pierre Bourdieu. Bourdieu har i flere af sine studier medtaget kønnets betydning i sine analyser af differentieringen af mennesker (Bourdieu 1996 og 1999). Bourdieus pointe er, at der opstår en særlig kønsdifferentiering, fordi de to køn følger en række skemaer, som i udgangspunktet er vilkårlige, men som ved at blive forbundet med den biologiske forskel mellem kvinder og mænd legitimeres, som udtryk for en naturlov (Bourdieu 1999, 14-16). Disse skemaer er indlejret i habitus, som kort fortalt udgøres af de erfaringer, som vi bærer med os i form af en praktisk sans for, hvordan vi skal handle i en given situation. Den praktiske sans kan være bevidst for mennesker, men er det oftest ikke. I den sociale proces, hvor skemaerne indlejres i den kønnede habitus, sker der således en naturalisering af vilkårlige sociale egenskaber, som enten klassificeres som kvindelige eller mandlige (Bourdieu 1999, 40-45). Men det er ikke kun sociale forskelle som konstrueres. Også den biologiske forskel bliver udsat for en social konstruktion, i og med dens betydning forstørres og forstærkes ved de socialt konstruerede kønsforskelle. Der bliver med andre ord tale om et cirkulært årsagsforhold mellem det sociale og det biologiske, der hele tiden bekræfter sig selv ved at henvise til hinanden (Bourdieu 1999, 18). Skemaerne kan i følge Bourdieu variere over tid og sted, men han finder i sine studier ligheder mellem dem på tværs af kulturer, selv om der ikke er tale om objektive klassificeringer af mandligt og kvindeligt (Bourdieu 1999, 133-137).

Bourdieu arbejder altid i sine teorier med dobbeltheden mellem struktur og individ. Han siger, at der finder en strukturering sted af både omgivelserne og kroppene. Når den omgivende verden er struktureret ud fra en bestemt orden, bliver de dispositioner, som er inkorporeret i kroppene, et billede af samme orden. Det betyder dog som nævnt ikke, at mennesker ikke kan handle anderledes, end ordenen byder. Men som regel vil vores dispositioner udtrykt ved den praktiske sans oftest være i overensstemmelse med den herskende orden (Bourdieu 1999, 51). Bourdieu skriver: "The habitus, a product of history, produces individual and collective practices - more history - in accordance with the schemes generated by history. It ensures the active presence and past experiences, which, deposited in each organism in form of schemes of perception, thought and action, tend to guarantee the "correctness" of practices and their constancy over time, more reliably than all formal rules and explicit norms" (Bourdieu 1990, 54).

Et eksempel på et "efterslæb" mellem objektive muligheder i vores omgivelser og de kønnede dispositioner, som vi ofte handler efter, findes $\mathrm{i}$ den forskel, der er mellem unge med og uden småbørn, når det gxlder tilknytningen til arbejdsmarked. 
Det forholder sig sådan, at en småbørnsfar arbejder mere og er mindre berørt af arbejdsløshed end jævnaldrende kønsfæller uden børn. Mens en småbørnsmor arbejder mindre og er mere berørt af arbejdsløshed end hendes jævnaldrende (Olsen 1993). Ud fra Bourdieus teori kan dette tolkes som udtryk for, at de dispositioner, som er inkorporeret i vores kønnede habitus i barndommen, er stærkere end de ligestillingsmæssige muligheder, som samfundet i dag giver for, at fædre kan tage orlov og gå på deltid og mødrene omvendt bevarer en mere stabil arbejdsmarkedstilknytning. Samtidig sker der dog også på andre planer en bekræftelse af dispositionerne, fordi moren og faren gennem svangerskabet, ved fødslen og i barselstiden oplever, hvordan sundhedspersonalet og forældreskabslekturen fremstiller morens "førsthed", når det gælder barnets omsorg (Se Madsen m.fl. 1999 og Dalsgaard i dette nummer).

\section{DEN ANDROCENTRISKE ORDEN}

Bourdieu betegner forholdet mellem kvindeligt og mandligt for den androcentriske orden i og med, at der ikke alene sker en opdeling af en række vilkårlige egenskaber i mandligt og kvindeligt, der sker også en inkorporering af en orden, som hierarkiserer mandligt over kvindeligt (Bourdieu 1999, 49). Bourdieu fremstiller dette, som alle mænds dominans over alle kvinder, men der finder også en differentiering sted inden for det enkelte køn. Den norske socio$\log$ Annick Prieur nuancerer denne fremstilling i en artikel med udgangspunkt i Bourdieus sociologi. Hun finder, at fordelingen af mandlige og kvindelige egenskaber følger fordelingen af økonomisk og kulturel kapital. Kvinder forbindes med den kulturelle kapital og mænd med den økonomiske (Prieur 1998, 140). Hjemmeværende fædre er derfor "i fare" for at blive forbundet med den kulturelle kapital, fordi de besidder en position, som er kvindeligt defineret. Den androcentriske orden anven- des således også til at differentiere mellem mænd indbyrdes. Jeg vil senere i artiklen vise, hvordan fædrene på orlov via sproget og ind imellem fysisk forsøger at fjerne sig fra hjemmet for ikke at blive forbundet med den underordnede kvindelige position.

Den norske sociolog Øystein Gulvåg Holter ligger på linie med Prieur i opfattelsen af, at privat-offentlig, som jo er en velkendt dikotomi, fortsat har en forklaringskraft, når vi ser på familier med spæd- og små-børn. Men han stiller spørgsmålstegn ved, om magtrelationen mellem kønnene, det Bourdieu kalder den androcentriske orden, kun skal forstås ud fra den maskuline dominans og den feminine underordning. Holter vender blikket mod magt- og arbejdsfordelingen i hjemmet. Han arbejder analytisk med cykelhjulet som metafor. Det kvindelige er navet, som er centrum i familien og hjemmet, og det mandlige er frlgen, som er perifer i forhold til centrum. Alle distributioner i familien går gennem navet, hvor kvinden fordeler dem. Hans pointe er at kvinder bliver ved med at dominere i hjemmet og familien. Det skyldes, at vi ændrer praksis, således at mænd varetager traditionelt kvindelige opgaver, så er vi tilbøjelige til fortsat at fortolke vores ansvar ud fra de traditionelle kønsroller, hvor kvinden udgør hjemmets centrum og faren periferien (Holter 1995). Her skal man erindre, at praksis faktisk ikke er ændret markant, når vi ser på kønsarbejdsdelingen i familierne, sådan som den danske økonom Jens Bonke gør i en række tidsanvendelsesstudier (Bonke 1995). Men Holters pointe kan godt anvendes i forhold til de grupper af fædre, hvor der faktisk sker en ændring i praksis, som hos de fredre der tager orlov.

\section{FORSKELLIGE BERETNINGER}

Interviewene med fædrene om deres orlovsliv er udført med det formål at indfange modsætninger og brud mellem på den ene side den interviewede fars fremstillinger af faderskabet og maskulinitetens betydning 


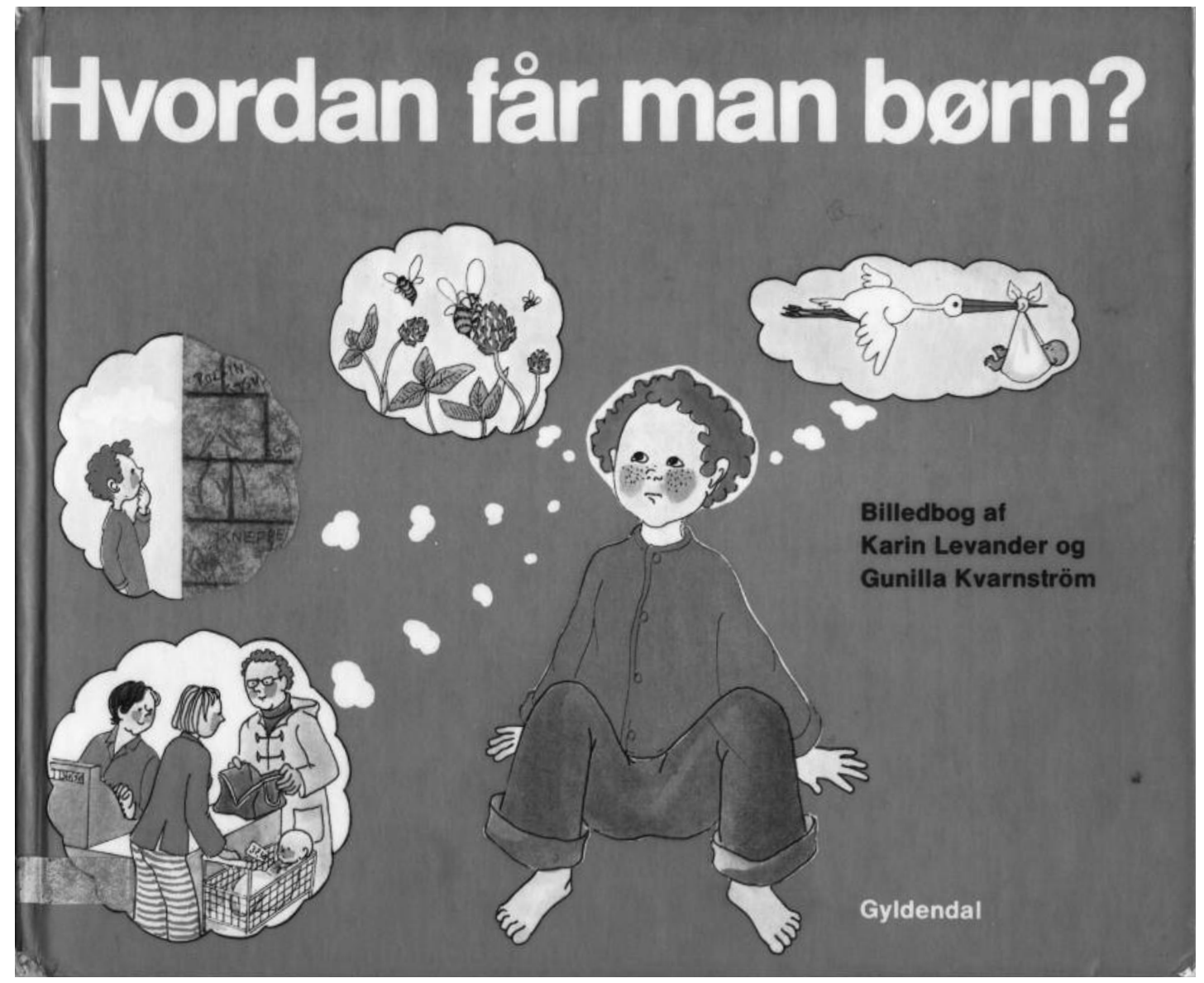

Forside på Karin Levander og Gunilla Kvarnström (1972/1978):

Hoordan fair man born? Gyldendal 
for dette og på den anden side det levede liv i praksis. Det teoretiske udgangspunkt var, som Holter citeres for, at der ofte er divergens imellem det, vi siger og det, vi faktisk gør. Man kan sige, at sproget kun stiller de kulturelle normer for, hvad en rigtig far og en rigtig mor er og gør, til rådighed. Det kræver derfor metodiske overvejelser, hvis man vil undersøge andre fortællinger $i$ interviewet end den fortælling, der allerede ligger informanterne på tungen. Den metodiske tilgang til dette dilemma har været at skabe en ramme for to forskellige fortællinger $\mathrm{i}$ interviewet. For det første talte jeg med fædrene om en række temaer, som eget faderskab set i forhold til moderskabet eller i forhold til ens egen fars faderskab. Det gav et "fortællerum" $\mathrm{i}$ interviewet for, at fædrene kunne fremstille sig selv og deres faderskab i de termer, man gængs vil anvende i sproget. Eller sagt med Bourdieu fædrene vil fremstille deres faderskab ud fra de kulturelle skemaer, som er indlejret i den kønnede habitus. For det andet havde jeg et andet fortællerum, som jeg kaldte "dagen igennem temaet", hvor fæedrene berettede om, hvad der skete, fra de stod op om morgenen, til de var oppe sidste gang om natten. Altså en fremstilling af den daglige praksis på en almindelig dag. Der var ikke altid overensstemmelse mellem fædrenes selvfremstillinger af eget faderskab og deres beskrivelser af den praktiske hverdag. I diskrepansen mellem de to fortællerum opstår muligheden for at analysere forandringer i faderskabet, hvilket jeg vender tilbage til (For en nuancering af metoden, se mit bidrag i Mac m.fl. 2001, 250-255 og Olsen 2000).

\section{MASKULINITET PÅ SPIL I MORS STED}

Når de interviewede fædre beretter om livet på orlov optræder kønnet som en vigtig markør til at vise forskel mellem dem og deres partnere. Fædrene markerer således forskel til mødrene og moderskabet i deres selvfremstillinger. På den ene side har disse fædre brudt med den kønnede praksis, at fædre normalt ikke tager orlov til spæd- eller småbørn, uden moren til barnet også er hjemme. På den anden side fører dette brud ikke til, at de nødvendigvis også bryder med andre kønnede praksiser i deres faderskab. Tværtimod bliver det måske endnu vigtigere at markere sit faderskab som maskulint, når man som mand indtager den feminine position i hjemmet, som i følge Bourdieu udgør en underordnet position.

Faren Søren siger:

“Så når jeg tænker over min faderrolle, så har det været sådan noget med at være et godt eksempel for Emil (parrets Søn). Han skal blive kærlig, og han skal blive omsorgsfuld, og selvstændig og have udfordringer, så det hele ikke bare bliver omsorg."

Søren fortæller videre om faderskabet, at han "bidrager med nogle mandlige sider" og samtidig kan han også varetage det, som han kalder for de moderlige sider:

"Trøste ham og lægge ham til at sove, og give ham mad." (Olsen 2000, 210).

Søren anvender kønsdikotomier i sin beretning om faderskabet, når han fremstiller det feminine som omsorg og nærhed og det maskuline som selvstændighed og udfordringer. I min fortolkning er der en modsætning $i$, at han både skulle kunne gøre en forskel på sønnens opvækst, fordi han er mand, men samtidig insisterer på selv at besidde både feminine og maskuline træk. Eksemplet viser, hvordan kønsskemaerne gør det indlysende for de fleste at forbinde vilkårlige egenskaber til biologisk køn uden at sætte spørgsmålstegn ved, om det biologiske køn nu også udgør et relevant kriterium for opdelingen.

Fædrene giver deres faderskab en maskulin betydning gennem en række temaer, som markerer forskel til moderskabet. De temaer, som går igen i flere af fædrenes beretninger om tiden på orlov er: at ønske at 
være meget uden for hjemmet, at vise økonomisk ansvarlighed (som er meget udbredt hos de arbejdsorienterede fredre, men næsten ikke hos de familieorienterede), at tage afstand fra husarbejde, at understrege at legen med barnet har maskuline elementer og at henvise til morens ansvarlighed og fortrin for at sørge for barnets mad, fordi hun engang har ammet det. Lad mig give nogle få eksempler fra interviewanalysen på nogle af temaerne (Olsen 2000).

\section{DE UDFARENDE FÆDRE}

Et gennemgående tema er, at fædrene opfatter det, at være uden for hjemmet med barnet, som et absolut gode. Det omtales af både de familie- og de arbejdsorienterede fædre som meget vigtigt for farens almene trivsel i orlovsperioden. De arbejdsorienterede fædre har svært ved at komme ud af huset. De er især i begyndelsen af orloven mere uvante end de familieorienterede fædre med barnets rytme og pasning, fordi de ifølge dem selv ikke har deltaget i den nære omsorg fra barnet blev født af, men udskudt det til de skulle have orlov og til barnet var lidt større. De arbejdsorienterede fæedre omtaler det som et stort problem, at de ikke når ud hver dag. Nogle taler om ensomhed, men også om rastløshed ved at gå inde, fordi de føler, at de ikke når noget i forhold til det, de plejer at overkomme på deres job. De familieorienterede frdre, som i modsætning til de arbejdsorienterede fædre kommer meget ud, forsøger i perioder at løfte faderskabet ud af hjemmet og dermed ud af det kvindelige domæne. De mest aktive af disse fædre tager spædbørn med på daglige lange ture i nærmiljøet. Og det er ikke nok blot at handle ind. Det er ture, gerne ud i naturen med små børn mellem 14 uger og lår. Og det kan ind imellem være ret besværligt at få skiftet ble og varmet en sutteflaske. En far fortæller om betydningen for både ham og sønnen på ca. 9 måneder om at være ude:
“Jo, han (sønnen) har helt sikkert nydt det. Altså hvis alternativet skulle være, at vi skulle gå rundt om hinanden her inde i huset en hel dag, så tror jeg nok, jeg blev irritabel eller i dårligt humør, men det bliver også for kedeligt. Så der har været mange dage, selv om det har været rigtig dårligt vejr, så har jeg rigget barnevognen til, og så er vi kørt. Hvor man så ellers har hængt tøj op til tørre, når man kom hjem igen.."

Jeg tolker fædrenes enslydende længsel efter at være uden for hjemmet med barnet, som en måde at markere et maskulint element i deres omsorg for barnet. Det at være ude $i$ det offentlige rum markerer faderskabets forskellighed fra moderskabet. Også selv om barnet er lille og omsorgsarbejdet med det fylder meget. Det er en måde at undgå at blive feminiseret på.

\section{FÆDRENES MARKERINGER AF FORSKEL}

Mange af fædrene fremhæver i det fortællerum, hvor de eksplicit taler om faderskabet, at der er stor forskel i den måde, de og deres partnere leger med barnet på. De fortæller, at de har en mere kraftpræget leg end moren, der leger stille lege med barnet. Flere fædre fortæller også, at de ved deres leg bibringer barnet en autonomi, som en mor ikke kan give. Men når de $\mathrm{i}$ det andet fortællerum, som omhandler "dagen igennem temaet", beretter om hvilke lege, som henholdsvis de selv og moren har med barnet, er der imidlertid ikke nogen forskel på morens og farens lege. Da der er tale om meget små børn, er de lege, som de fleste fædre nævner i dagen igennem temaet, ikke overraskende lege som "borte-borte-tittit”, tage fat og give slip på ting-lege, cykle med børnenes ben-lege ved bleskift og pjaske med vand under badningen.

Jeg fortolker de forskellige beretninger i de to fortællerum om legen, som udtryk for, at fædrenes behov for at markere forskel til moderskabet kun optræder, når de skal berette om deres eget faderskab. Her 
trækker de på kønsdikotomier for at understrege, at de indtager en anderledes position end moren i hjemmet og familien. De fjerner sig dermed fra en underordnet position ved at markere maskuline elementer i deres omsorg for børnene. Det samme gxlder husarbejdet, som mange fredre tager afstand fra, når jeg direkte spørger til om de tager sig af det i hverdagen. Men deres beretninger om hvordan dagen forløber er fulde af husarbejde. Holters metafor om cykelhjulet placerer mødrene i en dominerende rolle $\mathrm{i}$ familien og fredrene $\mathrm{i}$ dens periferi, uanset hvilke ændringer der indtræffer $\mathrm{i}$ familien. Modellen bekræftes på sin vis i min empiri. Fædrene tager afstand fra at indtage kvindens plads i centrum af familien, når de skal fortælle om deres eget faderskab, men mange af dem indtager den i praksis.

Jeg finder altså hos de nye fædre på orlov en række temaer, som markerer forskelle mellem faderskabet og moderskabet. De interviewede fædre havde $\mathrm{i}$ interviewsituationen mulighed for at berette om deres faderskab i to forskellige "fortællerum". Det blev her tydeligt, at deres vægt på maskuline og feminine egenskaber skiftede karakter alt efter konteksten i interviewet. Talte de om deres faderskab, fremhævede de ofte naturaliserede egenskaber ved det, mens de $\mathrm{i}$ andre situationer ikke pointerede køn som noget, der skabte forskelle mellem moderog faderskabet. Pointen er, at så snart, der tales om faderskab, associerer de fleste personer allerede til de naturaliserede skemaer for kønnede egenskaber. Men løsrives fortællingen om faderskabet fra denne forbindelse, ved for eksempel at tale om dagens gang, associeres der til andre forhold. Metoden giver mulighed for, at analyserer nye træk ved faderskabet. På den ene side så vi, at fædrene gav udtryk for kønsdikotome forestillinger, men samtidig kunne metoden opfange forandringer i retning af større ligestilling mellem moren og faren i orlovsfamilierne.

\section{DE NYE OG DE TRADITIONELLE FÆDRE}

Den mest fremførte begrundelse, for at fædre vælger orlov fra, er, at orlovsydelsen er for lav. Da fæedre tjener mere end mødre, kan det ikke svare sig for parret, at han tager orlov. En anden begrundelse er, at ordningerne er for ufleksible, så de ikke matcher mænds arbejdssituation. I debatten har muligheden for kortere orlovsperioder og halvdagsorlov ofte været nævnt som løsninger til at få flere fædre på orlov. Problemet vil nok bare ikke løses ved det, idet småbørnsfædre aldrig vælger deltidsarbejde. Desuden vil den økonomiske barriere stadig være der. En tredje begrundelse for fædres fravalg af orlov er, at arbejdspladskulturen er for gammeldags og ufleksibel. Fædre på orlov straffes efterfølgende med manglende lønstigninger og forfremmelser. Kollegaerne skal lave arbejdet eller det ligger tilbage efter endt orlov pga. manglende vikardækning. Den manglende vikardækning hænger ofte sammen med, at der sjældent er barselsfonde på mandearbejdspladser. (Olsen 1997 og 2000).

De nævnte barrierer for fædrenes valg af orlov er helt sikkert en del af fædrenes fravalg, men de må suppleres med andre forståelser. De få fædre på orlov og deres beretninger om faderskabet udlevet i et feminint domæne giver et andet bud på, hvorfor mange fædre slet ikke når til at overveje at tage orlov. Fædrene bremses af de kønsstereotype forestillinger, som blokerer for at forestille sig selv på orlov, fordi der er sket en naturalisering af mødrenes forrang til at passe de mindste børn. Det bliver med andre ord kulturelt utænkeligt for begge forældre og deres omgivelser, at faren skal holde orlov til det lille barn i stedet for mor. Jeg har således argumenteret imod den forestilling, at orlovsvalget primært er et bevidst, rationelt valg. Det er næppe i mange familier, at faren og moren over køkkenbordet diskuterer orlov ud fra, hvem af dem, der tjener mest, hvem, der har en arbejdsplads, der bedst kan undvære én, og 
hvem, der har de bedste kvalifikationer for at passe barnet (Olsen 2000).

Det subtile element, i hvilke egenskaber en god mor og en god far skal have, understreges også af et gennemgående tema i orlovsfædrenes beretninger. Alle fædrene talte om, hvor vigtigt det var for dem, at opnå respekt for deres valg af orlov blandt andre mænd. Men det opnåede de ikke altid. Til gengxld fik de respekt fra kvinder både på arbejdspladsen og $\mathrm{i}$ det offentlige rum. Dette modsvaredes af, at alle fædrenes koner havde oplevet at blive kritiseret af andre kvinder for at overlade orloven og barnet til faren (Olsen 2000, 254). Vi har den paradoksale situation, at nogle kvinder opmuntrer til mænds valg af orlov, mens nogle måske de samme - kritiserer kvinder for at overlade barnet til faren under en orlov. Sat på spidsen kan fædrene ikke bruge kvindernes opbakning til så meget, da det er deres eget køns respekt, de ønsker. Og af dem bliver de ofte tiet ihjel. Der er således gode forklaringer på, hvorfor fædre og mødre fastholder sig selv og hinanden i to kønsforskellige orlovsmønstre.

\section{Noter}

1. Statistikken følger intentionen med lovgivningen. Lov om Orlov til børnepasning sigter mod den enkelte arbejdstager eller ledige. Retten til orlov følger således ikke det enkelte barn, men er en individuel ret, hver forældre har. Både far og mor kan vælge at have orlov samtidig eller hver for sig. Man kan derfor ikke fă oplysninger om forældrepars benyttelse af orlov til deres børn, kun om enkeltpersoners.

2 . Om den kommende lov om en forlængelse af barselsorloven vil få flere fædre på orlov, kan man endnu kun gisne om. Men det er ikke sandsynligt, at det bliver tilfældet, da der ikke er blevet kvoteret en del af orloven til faren. Det, viser forskningen, er nødvendigt, hvis man skal motivere flere fædre til at anvende deres orlovsrettigheder på linie med mødre (Olsen 2000, 147).

\section{LITTERATURLISTE}

- Bonke, Jens (1995): Arbejde, tid og køn - I udvalgte lande. Socialforskningsinstituttet 95:4, København.

- Bourdieu, Pierre (1990): The Logic of Practice. Polity Press, Cambridge.

- Bourdieu, Pierre (1996): Symbolsk makt. Artikler i utvalg. Pax forlag, Oslo.

- Bourdieu, Pierre (1999): Den maskuline dominans. Tiderne skifter, København.

- Bäck-Wiklund, Margareta og Birgitta Bergsten (1997): Det moderna föräldraskapet en studie av familj og kon i förändring. Natur og Kultur, Stockholm.

- Dalsgaard, Anne Line (2001): Overgang eller sidespor? Danske kvinder pà barsel. In this column. - Holter, Øystein G. (1995): Family Theory Reconsidered. In Tordis Borch Grevink and $\varnothing$. G. Holter (ed): Labour of Love. Beyond the selfevidence of erveryday life. Avebury.

- Haavind, Hanne (1985): Förandringar i förhållandet mellan kvinnor og män. In Kvinnovetenskapligt Tidskrift nr. 3. 1985, Lund.

- Haavind, Hanne (1987): Liten og stor. Bind 17 i serien: Kvinners levevilkår og livsløp. Universitetsforlaget, Oslo.

- Mac, A., M. Godskesen, H. Fredslund, L. Dalager og B. M. Olsen (2001): Hårde nødder, der skal knækkes i den kvalitative arbejdsproces. In K. Bransholm Pedersen og L. Drewes Nielsen (red): Kvalitative metoder -fra metateori til markarbejde. Roskilde Universitets Forlag.

- Madsen, Svend Åge, Hanne Munck og Marianne Tolstrup (1999): Fadre og Fødsler. Frydenlund, København.

- Olsen, Bente Marianne (1993): Mens vi venter på far. Sociologisk kandidatafhandling. Sociologisk Institut, Københavns Universitet.

- Olsen, Bente Marianne (1997): Orlov til bornepasning - en familiepolitisk revolution? In Kvinder, Køn og Forskning nr. 2. 1997, København.

- Olsen, Bente Marianne (2000): Nye fadre på orlov - en analyse af de konsmessige aspekter ved foraldreorlovsordninger. Sociologisk Ph.d.afhandlingsserie nr. 14, Københavns Universitet.

- Prieur, Annick (1998): Forholdet mellom kjønn og klasse med udgangspunkt $i$ Bourdieus sosiologi. In Sosiologisk tidsskrift nr. 1/2 1998 - 6 årgang, Oslo.

\section{SUMMARY}

The article deals with the few fathers, who are on leave to take care of an infant, where the 
mother is not on leave at the same time. The article focuses on the fathers' representation of their fatherhood and it illustrates how the fear of feminisation and the tendency to represent fatherhood in masculine terms dominate considerate fathers on leave. The analys- is is based upon Pierre Bourdieu's notions of naturalisation of gender differences and androcentric dominance.

Bente Marianne Olsen, sociolog, ph.d. forsker på Socialforskningsinstituttet 